\title{
Training of Growers and Extension Agents in the Dominican Republic on Managing Heat Stress of Bell Pepper (Capsicum annum L.) Grown in High Tunnels
}

\author{
Juan Carlos Díaz-Pérez ${ }^{1,3}$ and Erick Smith ${ }^{2}$ \\ Department of Horticulture, Tifton Campus, University of Georgia, 2360 Rainwater Road, Tifton, GA 31793-5766
}

Additional index words. climate change, fruit sunscald, heat stress, greenhouse, cooling, Phytophthora capsici

\begin{abstract}
The Dominican Republic is located in the Hispaniola Island in the Caribbean region. Its climate differs substantially over short distances and is the most diverse of the Caribbean. Annual average temperature is $25{ }^{\circ} \mathrm{C}$, ranging from $18^{\circ} \mathrm{C}$ (at higher elevations) to $28^{\circ} \mathrm{C}$ (at sea level). Average annual rainfall is $1500 \mathrm{~mm}$. Although sugar, coffee, cocoa, and tobacco are the principal cash crops of the country, peppers are increasing in popularity on the country's exportation market. Bell peppers grown in high tunnels and greenhouses may be impacted by high temperatures that result in reduced fruit yield and quality. In this article, we make a short review of cooling techniques for high tunnels and share the experience of training bell pepper growers and extension personnel from the Dominican Republic regions of San José de Ocoa and Constanza on how to manage heat stress of bell peppers grown inside high tunnels. Bell pepper plants inside high tunnels showed symptoms of heat stress, including reduced plant and fruit size, small fruit number, and a mild leaf chlorosis. In both regions, but particularly in the warmer region, San José Ocoa, because of occurrences of high temperatures inside the high tunnels, growers were advised to use well-ventilated high tunnels, such as structures with plastic film on the top and screen net on the sides. Other strategies such as shade nets (30\% to $40 \%$ shade) placed on top of the high tunnel or whitewash paint applied on the high tunnel cover may also help reduce air and soil temperatures inside the tunnel. Use of white or silver reflective mulch, instead of the commonly used black mulch, may provide additional reduction of soil temperature. In conclusion, high tunnel structures developed for temperate regions, with limited to poor ventilation, may result in excessively high temperatures inside the high tunnels and thus were not recommended for the Dominican Republic regions of this study. More research is necessary on adequate high tunnel design and cooling techniques for high tunnel production, particularly in tropical regions.
\end{abstract}

In this article, we make a short review of cooling techniques for high tunnels in tropical regions and share the experience of training bell pepper growers and extension personnel from the Dominican Republic regions of San José de Ocoa and Constanza on how to manage heat stress of bell peppers grown inside high tunnels.

High tunnels are protected agricultural structures or hoop houses, but they are not greenhouses, although in much of the international literature high tunnels are referred to as "greenhouses." High tunnels have a pipe or other framework covered by a single layer of greenhouse-grade (100- to $150-\mu \mathrm{m}$ thick) plastic, and no electrical service, automated ventilation or heating system, and can have various structural designs from single span to multispan. Greenhouses, by contrast, provide significantly more environmental

Received for publication 11 May 2017. Accepted for publication 6 July 2017.

This paper was presented during the 2016 ASHS Annual Conference, Atlanta, GA, as part of the Workshop titled "Seize Your Future Internationally: New Opportunities in Horticultural Consulting."

Our sincere gratitude to Florida International Volunteer Corps (FAVACA) and Rafael Ledezma of Farmer to Farmer in Dominican Republic for their invitation and financial support of Díaz-Pérez for the trip to the Dominican Republic. We appreciate the thorough review of the manuscript by the anonymous reviewers.

${ }^{1}$ Professor.

${ }^{2}$ Assistant professor.

${ }^{3}$ Corresponding author. E-mail: jcdiaz@uga.edu. control compared with high tunnels (Cuce et al., 2016).

High tunnels capture infrared (IR) solar radiation ("thermic or greenhouse effect") resulting in increased temperatures inside the tunnel relative to outdoor conditions (Cuce et al., 2016; Rault, 1988). The benefits high tunnels provide depend on the crop and the geographical characteristics of the area (Lamont, 2009).

\section{TEMPERATE AREAS}

High tunnels were initially used in temperate regions to provide warmer temperature conditions for vegetable crop production during the cool environment of the spring and fall (Lamont, 2009). The difference in temperature inside and outside the high tunnels depends on various factors including high tunnel shape, height, and width, and cover type, light permeability of the cover, and ventilation. The warmer conditions inside the tunnels allow extending the production season. High tunnels also exclude the crop from rain, thus reducing the disease pressure and crop loss while improving crop quality and shelf life (Benincasa et al., 2014). In temperate climates where the field growing season is reduced, high tunnels allow tomato (Hunter et al., 2012) and strawberry (Kadir et al., 2006) production to begin at least one month earlier than in the field. In Canada, organic bitter melons (Momordica charantia L.) inside high tunnels had increased yields and increased plant growth, advanced harvest timing, reduced pest populations and disease incidence, increased individual fruit weight and size, and reduced postharvest fruit water loss (Kong et al., 2017).

\section{TROPICAL AND SUBTROPICAL AREAS}

High tunnels use has increased in subtropical and tropical areas allowing to extend growing seasons for crops such as tomatoes and peppers. The "classical" high tunnel (plastic cover buried on the sides, without gable ends) used in temperate areas, however, may be inadequate for tropical regions because the temperatures inside the tunnels may be excessively high for many vegetables (Lamont, 2009; Rault, 1990). The thermal conditions inside the high tunnel depend on the latitude and other geographical characteristics, such as altitude.

High temperatures inside the high tunnels may occur during the summer in temperate regions (locations with latitudes higher than $40^{\circ}$ north or south of the equator); during the spring, summer, or fall in subtropical regions (areas between the tropic circle at $23^{\circ} 26^{\prime}$ of latitude and locations lower than $40^{\circ}$ of latitude); and during all year in tropical regions (areas within $23^{\circ} 26^{\prime}$ north and south of the equator) (Lee et al., 2015; Moran, 2010). In the island of Martinique, maximal daily air temperature during a sunny day was found to be $\approx 36.5^{\circ} \mathrm{C}$ inside the high tunnel and $30.5^{\circ} \mathrm{C}$ in open field (Rault, 1988).

In the tropics, seasons are commonly determined more by rainfall (dry and wet 
seasons) than by temperature. Low air temperatures seldom restrict plant growth, and they tend to oscillate little during the year (Wilczek et al., 2010). In humid tropical regions, the "umbrella effect" of tunnels to protect the crop from excess rainfall may be of greater benefit than the thermic effect, whereas in arid tropical areas the "oasis effect" may be more valuable (Rault, 1988).

\section{MANAGEMENT OF EXCESS HEAT}

Strategies for management of crop heat stress are relevant to agricultural and horticultural production, because of augmented temperatures in many regions as result of climate change (DaMatta et al., 2010). Management of air temperature inside the high tunnels to prevent occurrence of excessive temperatures is essential to maximize fruit yield and quality in tropical areas (Kumar et al., 2009). Some of the techniques used to reduce temperatures inside the high tunnels include the use of shading nets, whitewash of film cover, and passive ventilation. Other strategies to cool high tunnels include use of tall high tunnel structures (up to about $4.5 \mathrm{~m})$.

\section{HIGH TUNNEL COVERS}

High tunnel covering materials vary in their impact on the environmental conditions inside of the high tunnel relative to the external environment (Castellano et al., 2008). Most high tunnel covers are made of polymeric films. Some plastic film covers have the ability to diffuse light inside the high tunnel and absorb or reflect IR light resulting in diminished temperatures inside the tunnel (Kumar et al., 2009). These types of films are popular in the Mediterranean area several tropical countries because they have a cooling effect and only reduce slightly the levels of photosynthetically active radiation inside the tunnel.

Use of insect-proof nets may be recommended in areas with high populations of insects such as thrips and whiteflies that transmit viral diseases. As the porosity of insect-proof decreases, however, aeration decreases resulting in augmented air temperatures inside the high tunnels (Kumar et al., 2009).

\section{SHADE NETS}

Shade nets are typically made out of plastic (high-density polyethylene or polypropylene) threads connected together with each other, in a woven or knitted pattern forming a regular porous geometric structure and allowing fluids to go through (Castellano et al., 2008). Shading nets are commonly black or may be of other colors (Elad et al., 2007; Fallik, 2009; Stamps, 2009). Colored shade nets have been found to affect physiological, morphological, and quality attributes of fruits and vegetables (Stamps, 2009). Aluminized shade nets have been reported to be more effective in reducing temperature inside the high tunnels compared with black shade nets (Callejón-Ferre et al., 2009). Shade nets decrease temperature by reducing light penetration inside the tunnel and can be placed either outside or inside the high tunnels. In addition to reducing temperature and solar radiation, shade nets protect crops from insects, wind, hail, and birds (Arthurs et al., 2013; Castellano et al., 2008).

Shade nets are widely used in tropical and subtropical countries for vegetable production (Castellano et al., 2008; El-Aidy et al., 1993; Ilic et al., 2012; Kittas et al., 2012; Rylski and Spigelman, 1986). Studies in Israel report that shade nets increase plant growth and yield (Rylski and Spigelman, 1986), reduce water requirements, and increase irrigation water use efficiency in bell pepper (Moller and Assouline, 2007). Shade nets have also been shown to extend the season in bell pepper grown in tunnels in Georgia and Florida, allowing for fruit production during the summer (Díaz-Pérez, 2014; Hochmuth et al., 2013). Shade nets are commonly used to modify the crop microenvironment with the goal of improving crop production (Castellano et al., 2008). Shade level has been found to affect plant growth, gas exchange, mineral nutrition, fruit yield and quality, and incidence of soilborne diseases in plastic-mulched bell pepper grown under shading nets (Díaz-Pérez, 2014).

\section{WHITEWASH}

Application of a solution of whitewash and water to the plastic film cover of the high tunnel is commonly used to reduce both incident solar radiation and temperature inside the structure (Callejón-Ferre et al., 2009). Whitewash is relatively inexpensive and easy to apply. Whitewash, however, requires additional application after a rain and is difficult to apply uniformly, resulting in areas within the high tunnel with either insufficient or excessive shading conditions. Chemical additives may be added to the whitewash to increase permanence on the plastic film surface.

\section{PASSIVE AERATION}

High tunnel design determines microclimate inside the tunnel (Kumar et al., 2009). Vent dimensions and positions are key factors in natural ventilation and temperature management (Benni et al., 2016; Teitel, 2001). Ventilation of a high tunnel is the exchange of air between the inside and outside to dissipate the excessive heat, increase the exchange of oxygen and carbon dioxide, and to manipulate relative humidity (Bartzanas et al., 2004).

In tropical and subtropical areas, temperatures inside the high tunnels commonly reach supraoptimal values because tunnels were originally developed for temperate areas. In the 1970 s, a wooden-framed polyethylene covered high tunnel was developed for French Guyana (Rault, 1988). This high tunnel combines continuous side and top ventilation, with dominant winds perpendicular to the high tunnel but blowing perpendicular to the openings, enhancing the rising of warm air. In low tropical regions, the design of high tunnels must typically be a compromise between ventilation and protection from heavy rains (Lamont, 2009; Rault, 1988; Rault, 1990). In Southeast Asia, high tunnel structures are pipe frames covered first with a screen net and with plastic film on top (Lamont, 2009).

\section{DOMINICAN REPUBLIC}

The Dominican Republic occupies the eastern two-thirds of the Hispaniola Island in the Caribbean region, and it is neighbor with Haiti (De la Fuente, 1976). The Dominican Republic is located in the tropics $\left(19^{\circ} 00^{\prime} \mathrm{N}, 70^{\circ} 40^{\prime} \mathrm{W}\right)$ and has a total surface of $48,670 \mathrm{~km}^{2}$. The central and western parts of the country are mountainous whereas the southeast consists of lowlands (González and Wiarda, 2017). Its climate shows considerable variation over short distances and is the most diverse of the Caribbean. Annual average temperature is $25^{\circ} \mathrm{C}$, ranging from $18^{\circ} \mathrm{C}$ at higher elevations (e.g., Constanza) to $28{ }^{\circ} \mathrm{C}$ in low, arid regions. Temperatures seldom are above $32{ }^{\circ} \mathrm{C}$ and freezing temperatures only occur in the highest mountains. Rain season is from November to January in the northern coast and from May to November for the rest of the country. Annual rainfall varies from 2500 (mountainous northeast) to $500 \mathrm{~mm}$ (southwester valleys), with an average of $1346 \mathrm{~mm}$. Although sugar, coffee, cocoa, and tobacco are the

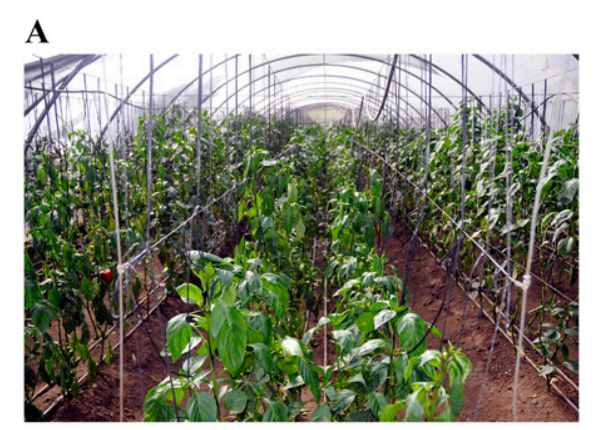

B

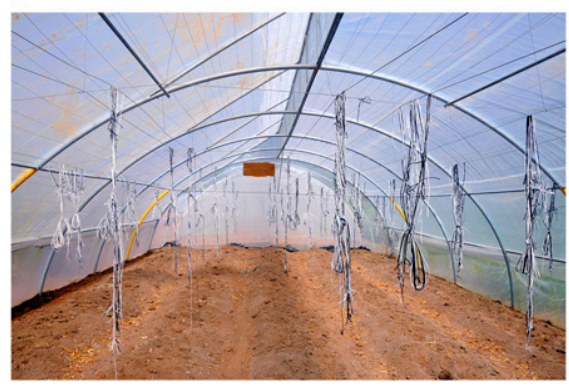

Fig. 1. High tunnel under bell pepper production (A) and at the end of the production cycle (B). High tunnel had no vents or openings for ventilation. San José de Ocoa, Dominican Republic. 
principal cash crops of the country, peppers (Capsicum spp.) are increasing in importance on the country's exportation market. Peppers are commonly grown in high tunnels and greenhouses, where producers are challenged by high temperatures that result in reduced fruit yield and quality.

One of us (Díaz-Pérez) conducted training to growers and extension personnel in the communities of San José de Ocoa (La Horma del Rifle and Las Auyamas) and Constanza on how to reduce temperatures inside the high tunnels. San José de Ocoa is in a valley at an altitude of $475 \mathrm{~m}$ (Pérez, 1969). Annual average minimal temperature is $18.6{ }^{\circ} \mathrm{C}$ (range 17.3 to $19.9^{\circ} \mathrm{C}$ ) and average maximal temperature is $30.4{ }^{\circ} \mathrm{C}$ (range 28.8 to $32.0^{\circ} \mathrm{C}$ ). Constanza is in a valley located at $1220 \mathrm{~m}$ of altitude in the heart of the Cordillera Central. Annual average minimal temperature is $11.8{ }^{\circ} \mathrm{C}$ (range 9.4 to $13.1{ }^{\circ} \mathrm{C}$ ), and average maximal temperature is $25.1^{\circ} \mathrm{C}$ (range 23.2 to $26.5^{\circ} \mathrm{C}$ ).

In San José de Ocoa, high tunnels had no vents or openings for ventilation (Fig. 1A and B). As expected, because of inadequate high tunnel design and presence of higher temperatures, temperatures inside the high tunnels were excessively high for bell peppers. Plants displayed severe symptoms of heat stress, including wilting, reduced plant and fruit size, small fruit number, and a leaf chlorosis. Poor plant growth in poorly ventilated high tunnels, under tropical conditions, has already been reported (Rault, 1988).

In Constanza, cooler environmental conditions were more conducive to grow bell peppers. In addition, high tunnels had lateral or zenithal vents, which allowed removal of excessive heat from inside the tunnels. However, despite the cooler conditions in Constanza, bell pepper plants also had occasional exposure to high temperatures inside the high tunnels.

In both regions, but particularly in the warmer region, San José Ocoa, growers were advised to use well-ventilated high tunnels, such as structures with plastic film on the top and screen net on the sides. Others strategies such as shade nets ( $30 \%$ to $40 \%$ shade) placed on top of the high tunnel or whitewash paint applied on the high tunnel cover may also help reduce air and soil temperatures inside the tunnel. Use of white or silver reflective mulch, instead of the commonly used black mulch, may provide additional reduction of soil temperature (Díaz-Pérez, 2010; Lamont, 2005).

In conclusion, high tunnel structures developed for temperate regions, with limited to poor ventilation, were not recommended for the Dominican Republic regions of this study. More research is necessary on adequate high tunnel design and cooling techniques for high tunnel production, particularly in tropical regions.

\section{Literature Cited}

Arthurs, S.P., R.H. Stamps, and F.F. Giglia. 2013. Environmental modification inside photoselective shadehouses. HortScience 48:975-979.

Bartzanas, T., T. Boulard, and C. Kittas. 2004. Effect of vent arrangement on windward ventilation of a tunnel greenhouse. Biosyst. Eng. 88:479-490

Benincasa, P., A. Massoli, L. Polegri, L. Concezzi, A. Onofri, and F. Tei. 2014. Optimising the use of plastic protective covers in field grown melon on a farm scale. Ital. J. Agron. 9:8-14.

Benni, S., P. Tassinari, F. Sonora, A. Barbaresi, and D. Torreggiani. 2016. Efficacy of greenhouse natural ventilation: Environmental monitoring and CFD simulations of a study case. Energy Build. 125:276-286.

Callejón-Ferre, A.J., F. Manzano-Agugliaro, M. Díaz-Pérez, A. Carreno-Ortega, and J. PérezAlonso. 2009. Effect of shading with aluminised screens on fruit production and quality in tomato (Solanum lycopersicum L.) under greenhouse conditions. Span. J. Agr. Res. 7:41-49.

Castellano, S., G.S. Mugnozza, G. Russo, D. Briassoulis, A. Mistriotis, S. Hemming, and D. Waaijenberg. 2008. Plastics net in agriculture: A general review of types and applications. Appl. Eng. Agr. 24:799-808.

Cuce, E., D. Harjunowibowo, and P.M. Cuce. 2016. Renewable and sustainable energy saving strategies for greenhouse systems: A comprehensive review. Renew. Sustain. Energy Rev. 64:34-59.

DaMatta, F.M., A. Grandis, B.C. Arenque, and M.S. Buckeridge. 2010. Impacts of climate changes on crop physiology and food quality. Food Res. Intl. 43:1814-1823.

De la Fuente, S. 1976. Geografia dominicana. Colegial Quisqueyana, Santo Domingo, Dominican Republic.

Díaz-Pérez, J.C. 2010. Bell pepper (Capsicum annum L.) grown on plastic film mulches: Effects on crop microenvironment, physiological attributes, and fruit yield. HortScience 45:1196-1204.

Díaz-Pérez, J.C. 2014. Bell pepper (Capsicum annum L.) crop as affected by shade level: Fruit yield, quality, postharvest attributes, and incidence of Phytophthora blight (caused by Phytophthora capsici Leon.). HortScience 49:891-900.

Elad, Y., Y. Messika, M. Brand, D.R. David, and A. Sztejnberg. 2007. Effect of colored shade nets on pepper powdery mildew (Leveillula taurica). Phytoparasitica 35:285-299.

El-Aidy, F., M. El-Afry, and F. Ibraheim. 1993. Effect of shade and fertilizer levels and their interaction on fruit yield of sweet pepper. Acta Agron. Hung. 42:59-67.

Fallik, E. 2009. Can colored shade nets maintain sweet pepper quality during storage and marketing? Acta Hort. 830:37-44.

González, N.L. and H.J. Wiarda. 2017. Dominican Republic. Encyclopædia Britannica, Inc.

Hochmuth, R.C., D. Treadwell, E.H. Simone, L. Landrum, W.L. Laughlin, and L.L. Davis. 2013. Growing bell peppers in soilless culture under open shade structures. University of Florida, IFAS Extension.

Hunter, B., D. Drost, B. Black, and R. Ward. 2012. Improving growth and productivity of early-season high-tunnel tomatoes with targeted temperature additions. HortScience 47:733-740.

Ilic, Z.S., L. Milenkovic, L. Stanojevic, D. Cvetkovic, and E. Fallik. 2012. Effects of the modification of light intensity by color shade nets on yield and quality of tomato fruits. Sci. Hort. 139:90-95.

Kadir, S., E. Carey, and S. Ennahli. 2006. Influence of high tunnel and field conditions on strawberry growth and development. HortScience 41:329-335.

Kittas, C., N. Katsoulas, N. Rigakis, T. Bartzanas, and E. Kitta. 2012. Effects on microclimate, crop production and quality of a tomato crop grown under shade nets. J. Hort. Sci. Biotechnol. 87:7-12.

Kong, Y., D. Llewellyn, K. Schiestel, M.G. Scroggins, D. Lubitz, M.R. McDonald, R. Van Acker, R.C. Martin, Y.B. Zheng, and E. Elford. 2017. High tunnels can promote growth, yield, and fruit quality of organic bitter melons (Momordica charantia) in regions with cool and short growing seasons. HortScience 52: $65-71$.

Kumar, K.S., K.N. Tiwari, and M.K. Jha. 2009. Design and technology for greenhouse cooling in tropical and subtropical regions: A review. Energy Build. 41:1269-1275.

Lamont, W.J. 2005. Plastics: Modifying the microclimate for the production of vegetable crops. HortTechnology 15:477-481.

Lamont, W.J. 2009. Overview of the use of high tunnels worldwide. HortTechnology 19:25-29.

Lee, A.C., F.S. Liao, and H.F. Lo. 2015. Temperature, daylength, and cultivar interact to affect the growth and yield of lettuce grown in high tunnels in subtropical regions. HortScience 50:1412-1418.

Moller, M. and S. Assouline. 2007. Effects of a shading screen on microclimate and crop water requirements. Irrig. Sci. 25:171-181.

Moran, J.M. 2010. Climate studies: Introduction to climate science. American Meteorological Society, Washington, D.C.

Pérez, M.J. 1969. Una contribución al conocimiento de la dinámica del clima de la isla de Santo Domingo. Instituto Interamericano de Ciencias Agrícolas de la OEA, Turrrialba, Costa Rica, MS Diss.

Rault, P.A. 1988. Protected crops in humid tropical regions. How could we avoid or reduce excessive temperatures? How could we select the cladding materials and the greenhouse design? Acta Hort. 230:565-574.

Rault, P.A. 1990. A tunnel greenhouse adapted to the tropical lowland climate. Acta Hort. 281:95-104.

Rylski, I. and M. Spigelman. 1986. Effect of shading on plant development, yield and fruit quality of sweet pepper grown under conditions of high temperature and radiation. Sci. Hort. 29:31-35.

Stamps, R.H. 2009. Use of colored shade netting in horticulture. HortScience 44:239-241.

Teitel, M. 2001. The effect of insect-proof screens in roof openings on greenhouse microclimate. Agr. For. Meteorol. 110:13-25.

Wilczek, A.M., L.T. Burghardt, A.R. Cobb, M.D. Cooper, S.M. Welch, and J. Schmitt. 2010. Genetic and physiological bases for phenological responses to current and predicted climates. Philos. Trans. R. Soc. Lond. Ser. B Biol. Sci. 365:3129-3147. 